\title{
Partial sequence and toxic effects of granulitoxin, a neurotoxic peptide from the sea anemone Bunodosoma granulifera
}

\author{
A.N.C. Santana ${ }^{1}$, A.B. Leite ${ }^{1}$, \\ M.S.F. França' ${ }^{1}$, L. França ${ }^{1}$, \\ O.C. Vale', R.B. Cunha ${ }^{3}$, \\ C.A.O. Ricart ${ }^{3}$, M.V. Sousa ${ }^{3}$ \\ and K.M. Carvalho ${ }^{1,2}$
}

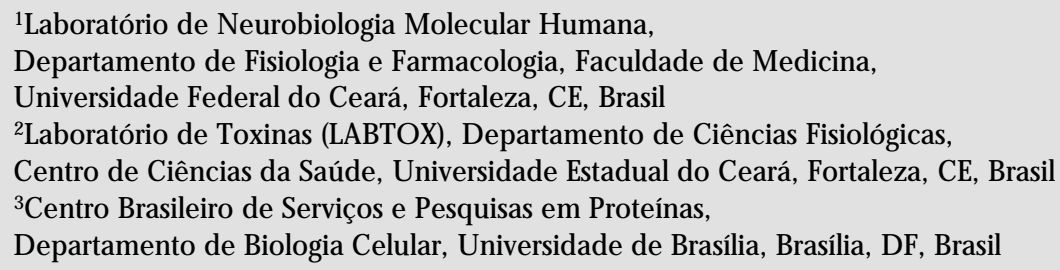

${ }^{1}$ Laboratório de Neurobiologia M olecular Humana, Departamento de Fisiologia e Farmacologia, Faculdade de Medicina, Universidade Federal do Ceará, Fortaleza, CE, Brasil '2Laboratório de Toxinas (LABTOX), D epartamento de Ciências Fisiológicas, Centro de Ciências da Saúde, Universidade Estadual do Ceará, Fortaleza, CE, Brasil ${ }^{3}$ Centro Brasileiro de Serviços e Pesquisas em Proteínas, Departamento de Biologia Celular, Universidade de Brasília, Brasília, DF, Brasil

\section{Correspondence \\ K.M. Carvalho \\ Laboratório de Neurobiologia \\ Molecular Humana \\ Departamento de Fisiologia e \\ Farmacologia \\ Faculdade de Medicina, UFCE \\ Rua Cel. Nunes de Melo, 1127 \\ 60430-270 Fortaleza, CE \\ Brasil}

Presented at the XIII Annual

M eeting of the Federação de

Sociedades de Biologia

Experimental, Caxambu, MG,

Brasil, August 26-29, 1998.

Research supported by CNPq, FINEP, FUNCAP, FAPESP and CAPES.

Received April 14, 1998 Accepted August 3, 1998

\section{Abstract}

A neurotoxic peptide, granulitoxin (GRX), was isolated from the sea anemone Bunodosoma granulifera. The N-terminal amino acid sequence of GRX is AKTGILDSDGPTVAGNSLSGT and its molecular mass is $4958 \mathrm{Da}$ by electrospray mass spectrometry. This sequence presents a partial degree of homology with other toxins from sea anemones such as Bunodosoma caissarum, Anthopleura fuscoviridis and Anemonia sulcata. However, important differences were found: the first six amino acids of the sequence are different, Arg-14 was replaced by Ala and no cysteine residues were present in the partial sequence, while two cysteine residues were present in the first 21 amino acids of other toxins described above. Purified GRX injected $i p$ $(800 \mu \mathrm{g} / \mathrm{kg})$ into mice produced severe neurotoxic effects such as circular movements, aggressive behavior, dyspnea, tonic-clonic convulsion and death. The $2-\mathrm{h} \mathrm{LD}_{50}$ of GRX was $400 \pm 83 \mu \mathrm{g} / \mathrm{kg}$.

Sea anemones possess tentacles which contain a variety of biologically active substances, including potent toxins, which are used for the capture of prey or for defense against predators. Toxic peptides have been isolated from several species of sea anemones, such as Anthopleura fuscoviridis (1), Anemonia sulcata (2), Radianthus paumotensis (3), Radianthus macrodactylus (4) and Bunodosoma caissarum $(5,6)$. Several of these peptides act on the voltage-sensitive sodium channel, inhibiting the inactivating phase of sodium currents during depolariza-

\section{Key words}

- Bunodosoma granulifera

- Sea anemones

- Toxic peptides tion and stabilizing channels in the open state without affecting the activation process (7). A peptide from Bunodosoma granulifera that acts as an inhibitor of potassium channel was recently isolated $(8,9)$. These studies show that these toxic peptides may be important tools for investigating ionic channels.

In the present study, a new neurotoxic peptide, called granulitoxin (GRX), was isolated from Bunodosoma granulifera, its partial sequence was determined and its neurotoxic effects in vivo were investigated.

Ten sea anemones (100 g), Bunodosoma 
Figure 1 - A, HPLC elution profile of a crude sample from Bunodosoma granulifera. The sample was dissolved in TFA at a proportion of $1: 4(\mathrm{w}: \mathrm{v})$. After centrifugation at $17,000 \mathrm{~g}$ for 60 min, the supernatant fraction was injected into an HPLC apparatus with a $\mathrm{C}_{18}$ column (Shimpack $25 \times 250 \mathrm{~mm}$ ) eluted with a $0-40 \%$ gradient of acetonitrile containing $0.05 \%$ TFA, over a period of $30 \mathrm{~min}$ at a flow rate of $5 \mathrm{ml} / \mathrm{min}$. The horizontal bar indicates the effluent containing neurotoxic activity that were combined. B, HPLC elution profile of an aliquot containing $10 \%$ of the purified toxin. The HPLC conditions are the same as used in panel $A$.

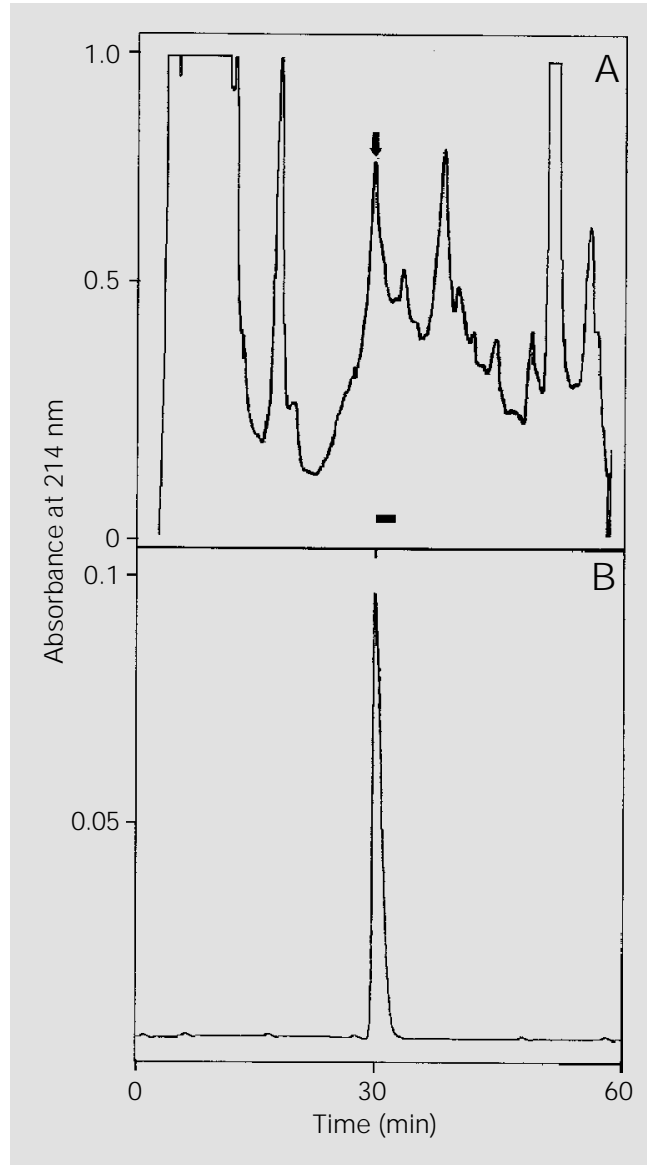

granulifera, collected along the north coast of Fortaleza city were homogenized in distilled water $(1 / 4, w / v)$ at $4^{\circ} \mathrm{C}$. The resulting suspension was centrifuged at $17,000 \mathrm{~g}$ for $60 \mathrm{~min}$. The supernatant was boiled $\left(100^{\circ} \mathrm{C}\right.$ for $5 \mathrm{~min}$ ) and acetic acid was added to obtain a final concentration of $5 \%(\mathrm{v} / \mathrm{v})$. After $30 \mathrm{~min}$, the suspension was centrifuged as described above, and the supernatant was lyophilized and kept at $-80^{\circ} \mathrm{C}$.

For purification of the neurotoxic peptide, the lyophilized material was dissolved in $5 \mathrm{ml}$ of $0.05 \%$ trifluoroacetic acid (TFA) and centrifuged as described above. The supernatant was fractionated by HPLC using a $\mathrm{C}_{18}$ column (Shim-pack PREP 25 x $250 \mathrm{~mm}$ ) eluted with a $0-40 \%$ gradient of acetonitrile containing $0.05 \%$ TFA, over a period of 30 min at a flow rate of $5 \mathrm{ml} / \mathrm{min}$. The effluent was lyophilized and stored at $-80^{\circ} \mathrm{C}$.
Acute toxicity tests were carried out and 2-h $\mathrm{LD}_{50}$ was determined by injecting the purified toxin intraperitoneally (ip) into the cavity of the mice, and physical and observation parameters were evaluated as described previously (10). Two groups of six mice (control and test) were used for each experiment. The results are reported as means \pm SEM.

The N-terminal sequence of GRX was determined using a Perkin Elmer-Applied Biosystems (Norwalk, CT) automated protein sequencer model 477A-120A modified for better recovery of PTH-Lys as described previously (11).

The mass of the native peptide was determined by mass spectrometry using a Perkin Elmer-Sciex API300 electrospray-triple quadrupole mass spectrometer according to Kalume et al. (12).

Figure 1A shows the fractionation of the crude sample of Bunodosoma granulifera by preparative HPLC. The neurotoxic activity was eluted between 60 and $70 \mathrm{ml}$, and $980 \mu \mathrm{g}$ of the neurotoxic peptide was obtained. The purity of the peptide was demonstrated by further HPLC of this fraction under the same conditions as described above (Figure 1B).

Mice injected $i p$ with $200 \mu \mathrm{g} / \mathrm{kg}$ of GRX presented increased locomotor activity, circular movements, aggressive behavior, dyspnea and increased sensitivity to touch and sound. These effects started $5 \mathrm{~min}$ after the injection and ended about 120 min later, with full animal recovery. The $2-\mathrm{h} \mathrm{LD}_{50}$ for GRX injected $i p$ was $400 \pm 83 \mu \mathrm{g} / \mathrm{kg}$, and the animals died with tonic-clonic convulsions. The $\mathrm{LD}_{50}$ of other anemone peptides varied widely: it was only $8 \mu \mathrm{g} / \mathrm{kg}$ for the Anthopleura xanthogrammica peptide (AP-B) and $4000 \mu \mathrm{g} / \mathrm{kg}$ for the Anemonia sulcata peptide (ATXI) $(13,14)$.

It is known that the $5000-\mathrm{Da}$ anemone peptides present neurotoxic effects by acting on the voltage-sensitive sodium channel, inhibiting the inactivating phase of sodium 
currents during depolarization, and stabilizing channels in the open state without affecting the activation process (7). Although the interaction of GRX with the voltage-gated sodium channel has not been studied, the in vivo neurotoxic effects described above suggest that it may act similarly to other anemone peptides.

The partial N-terminal amino acid sequence of GRX is shown in Figure 2. The peptide presented a molecular mass of 4958Da by electrospray mass spectrometry.

Three classes of 5000-Da anemone peptides that act by binding to the voltage-gated sodium channel have been described according to amino acid sequences (7): the first comprises toxins from Anemonia sulcata, Anthopleura xantogrammica, Anthopleura fuscoviridis and Bunodosoma caissarum, the second comprises toxins from Radianthus macrodactylus, Radianthus paumotensis and Stichodactyla helianthus, and the third comprises the Calliactis parasitica toxin.

The N-terminal GRX sequence contain- ing 21 amino acids only presents a partial degree of homology with the sequences of these three classes of toxic peptides (Figure 2), i.e., 57\% with Anthopleura fuscoviridis toxin I (AfI), 35\% with Radianthus macrodactylus toxin I (HmI) and $22 \%$ with Calliactis parasitica toxin (CLX). The sequence of the first six N-terminal amino acids is totally different from those of the three classes, with emphasis on the fact that no cysteine residues are present in the partial sequence. The sequence of residues 7 and 21 of GRX is similar to those of the three classes of anemone peptides.

There is general agreement that the flexible region between residues 7 and 14 of these peptides is important to make contact with the sodium channel and that Gly-10 and Pro-11 are important in maintaining the biologically active conformation of this region (7). Furthermore, it has been accepted that Asp-9 and Arg-14 are "functional", both playing an important role in binding and toxic action. However, the replacement of

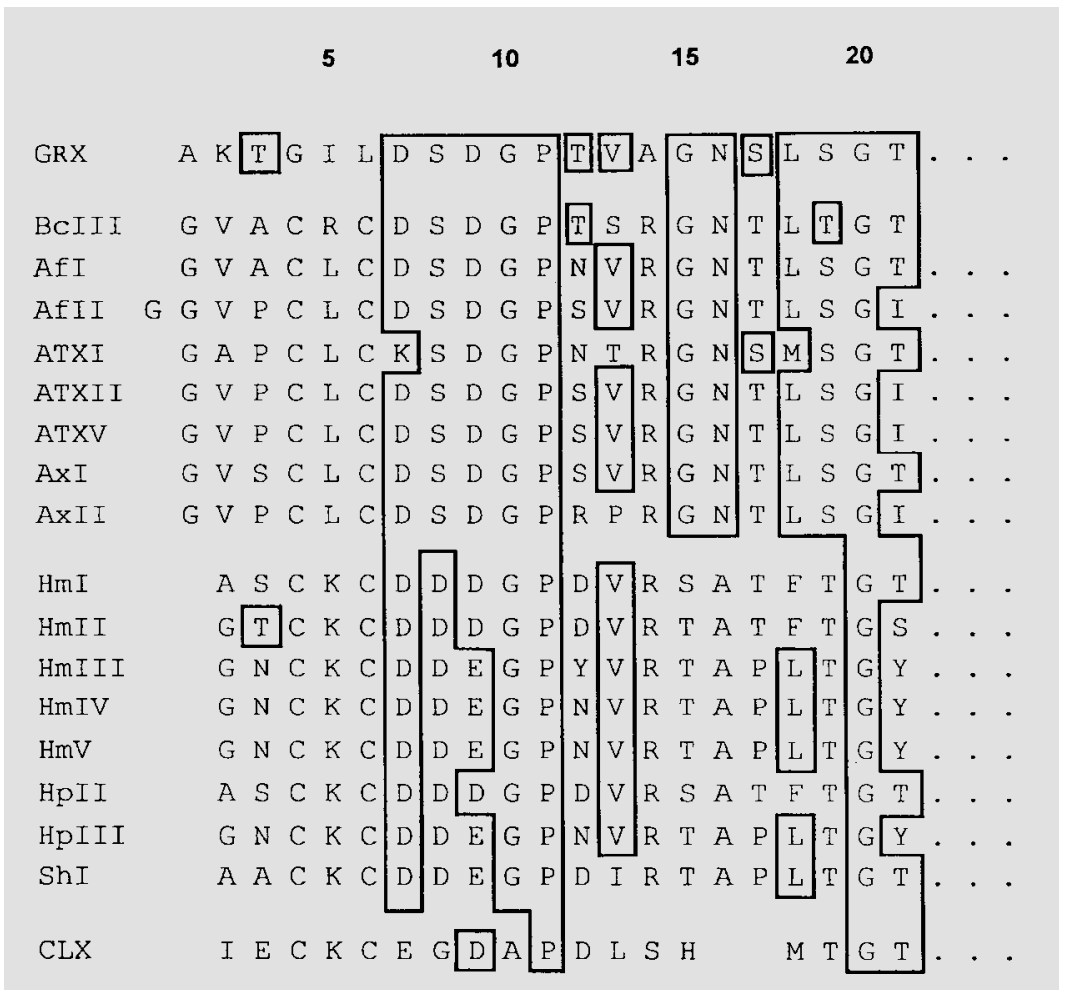

Figure 2 - Partial amino acid sequences of GRX, type 1 , type 2 and type 3 long polypeptides from sea anemones. Identical residues are boxed. GRX was obtained from Bunodosoma granulifera, Bclll from Bunodosoma caissarum, AfI and AfII from Anthopleura fuscoviridis, ATXI, ATXII and ATXV from Anemonia sulcata, AxI and AxII from Anthopleura xanthogrammica, Hml, Hmll, Hmlll, HmIV and $\mathrm{HmV}$ from Radianthus macrodactylus, $\mathrm{Hpll}$ and $\mathrm{Hplll}$ from Radianthus paumotensis, Shl from Stichodactyla helianthus, and CLX from Calliactis parasitica (7). 
Arg-14 by Ser- 14 in the amino acid sequence of the Calliactis parasitica toxin suggests that this residue is not absolutely essential for activity (15).

The sequence 7-14 of GRX is very similar to those of the three classes of anemone peptides, containing almost all of the residues described above, except for an important difference: similar to the Calliactis parasitica toxin, the Arg-14 of GRX is also replaced by another amino acid, Ala-14. Sur- prisingly, Ala at this position is not present in any class of these peptides.

In conclusion, the present results suggest that GRX may be a neurotoxic peptide representative of a new class of 5000-Da anemone peptides that act by binding to the voltagegated sodium channel. However, further studies are necessary to determine the total sequence of this new peptide and the mechanism of its neurotoxic action.

\section{References}

1. Sunahara S, Muramoto K, Tenma K \& Kamyia H (1987). Amino acid sequence of two sea anemone toxins from Anthopleura fuscoviridis. Toxicon, 25: 211-219.

2. Wunderer G \& Eulitz M (1978). Amino acid sequence of toxin I from Anemonia sulcata. European J ournal of Biochemistry, 89: 11-17.

3. Schweitz H, Bidard J N, Frelin C, Pauron D, Vijverberg HPM, Mahasneh DM, Lazdunski M, Vilbois F \& Tsugita A (1985). Purification, sequence and pharmacological properties of sea anemone toxins from Radianthus paumotensis. A new class of sea anemone toxins acting on the sodium channel. Biochemistry, 24: 3554-3561.

4. Mahnir VM \& Kozlovskaya EP (1991). Structure-toxicity relationships of neurotoxins RTX-III from the sea anemone Radianthus macrodactylus: modification of amino groups. Toxicon, 29: 819-826.

5. Malpezzi ELA \& Freitas JC (1991). Hemolytic activity of the nematocyst venom from the sea anemone Bunodosoma caissarum. Brazilian J ournal of Medical and Biological Research, 24: 1245-1249.

6. Malpezzi ELA, Freitas J C, Muramoto K \& Kamyia H (1993). Characterization of peptides in sea anemone venom collected by a novel procedure. Toxicon, 31: 853-864.
7. Norton RS (1991). Structure and structure-function relationships of sea anemone proteins that interact with the sodium channel. Toxicon, 29: 1051-1084.

8. Cotton J, Crest M, Bouet F, Alessandri N, Gola M, Forest E, Karlsson E, Castaneda O, Harvey AL, Vista C \& Menez A (1997). A potassium-channel toxin from the sea anemone Bunodosoma granulifera, an inhibitor for kvl channels. Revision of the amino acid sequence, disulfide-bridge assignment, chemical synthesis, and biological activity. European J ournal of Biochemistry, 244: 279-282.

9. Aneiros A, Garcia-Alonso I, Martinez J R, Harvey AL, Anderson AJ, Marshall DL, Emgstrom A, Hellman $U$ \& Karlsson $E$ (1993). A potassium channel toxin from the secretion of the sea anemone Bunodosoma granulifera. Biochimica et Biophysica Acta, 1157: 86-92.

10. Loomis TA \& Hayes AW (1996). Toxicologic testing methods. In: Loomis TA \& Hayes AW (Editors), Loomis's Essentials of Toxicology. Academic Press, Inc., San Diego, CA, 205-248.

11. Fontes $W$, Cunha RB, Sousa $M V \&$ Morphy LM (1998). Improving the recovery of lysine in automated protein sequencing. Analytical Biochemistry (in press).

12. Kalume DE, Sousa MV \& Morphy LM (1995). Purification, characterization, sequence determination and mass spectrometric analysis of a trypsin inhibitor from seeds of the Brazilian tree Dypteryx alata (Leguminosae). J ournal of Protein Chemistry, 14: 685-693.

13. Schweitz $H$, Vincent J $P$, Barhanin J, Frelin $C$, Linden $G$, Hugues $M \&$ Lazdunski $M$ (1981). Purification and pharmacological properties of eight sea anemone toxins from Anemonia sulcata, Anthopleura xantogrammica, Stoichactis giganteus and Actinodendron plumosum. Biochemistry, 20: 5245-5252.

14. Schweitz $H$ (1984). Lethal potency in mice of toxins from scorpion, sea anemone, snake and bee venoms following intraperitoneal and intracisternal injection. Toxicon, 22: 308-311.

15. Cariello L, De Santis A, Fiore F, Piccoli R, Spagnuolo A, Zanetti L \& Parente A (1989). Calitoxin, a neurotoxic peptide from the sea anemone Calliactis parasitica: Amino acid sequence and electrophysiological properties. Biochemistry, 28: 2484-2489. 